\title{
Detection of the metabolic activity of cells by differential measurements based on a single light-addressable potentiometric sensor chip
}

\author{
S. Takenaga ${ }^{1}$, C. Herrera ${ }^{1}$, C. F. Werner ${ }^{1}$, M. Biselli $^{1}$, Th. Schnitzler ${ }^{1}$, M. J. Schöning ${ }^{1}$, \\ P. Öhlschläger ${ }^{1}$ and T. Wagner ${ }^{1}$ \\ ${ }^{1}$ Institute of Nano- and Biotechnologies, Aachen University of Applied Sciences, Jülich, GERMANY \\ takenaga@fh-aachen.de
}

\begin{abstract}
:
The metabolic activity of Chinese hamster ovary $(\mathrm{CHO})$ cells was successfully observed using a lightaddressable potentiometric sensor (LAPS). The dependency of the different glucose concentrations $(17-200 \mathrm{mM})$ follows a Michaelis-Menten kinetics like trajectory. Moreover, a good adhesion of $\mathrm{CHO}$ cells on the $\mathrm{Ta}_{2} \mathrm{O}_{5}$ surface of the sensor chip was observed, and the cells could culture under normal conditions. These results demonstrate the detection of the metabolic response from cells by means of a LAPS-based set-up.
\end{abstract}

Key words: Light-addressable potentiometric sensor, Cell metabolism, Michaelis-Menten kinetics, Chinese hamster ovary cells, Multi-analyte diagnostic.

\section{Introduction}

Biochip array technology has received considerable attention in biological and medical fields as a multi-analyte diagnostic tool, e.g., for a fast and cost-effective drug screening [1-3]. This technology can be applied to simultaneously detect multiple reactions that occur in living cells or to monitor cell-to-cell interactions.

The light-addressable potentiometric sensor (LAPS) [4-8] as a semiconductor-based biosensor has been recently utilized for monitoring the metabolism of cells by detection of the acidification rate [9]. In previous cell metabolic measurements, unexpected disturbances, e.g., conductance changes of the analyte solutions, $\mathrm{pH}$ variation for different media, temperature changes and parameter shifting of the used measurement and control electronics, will become a considerable problem to deal with especially, small sensor signals such as obtained from cell activity measurements. A differential measurement signal by subtracting the parallel-recorded background signal obtained from a blank area on the same sensor chip should improve the net signal generated by cell activity. Furthermore, the LAPS principle enables the design of miniaturized, single chip set-ups. This could lead to the development of a new type of diagnostic systems for monitoring of cell activities with more precision and reliability. Towards this development, the possibility of cell metabolism measurements by using LAPS should be demonstrated. In this work, the cell metabolism and background signal were simultaneously measured on a single LAPS chip and the cell metabolic activity was analyzed.

\section{Materials and Methods}

Figure 1a depicts schematically the LAPS principle. The LAPS structure consists of a single electrolyte/insulator/semiconductor (EIS) structure. Because of illumination from the rear-side, the rear-side Al-contact is removed partly. The concentration change of the local analyte on the sensor surface influences the spacecharge region at the insulator/semiconductor interface. Targeting a focused and modulated light into the semiconductor, electron-hole pairs are generated. If these electron-hole pairs move to the space-charge region they will be separated, and thus a measurable external photocurrent $I_{p h}$ will occur. The photocurrent $I_{p h}$ depends on the local width of the spacecharge region at the illuminated area and consequently, on the local concentration of the analyte of interest on the sensor surface. The used LAPS set-up consists of thin films of $\mathrm{Ta}_{2} \mathrm{O}_{5}, \mathrm{SiO}_{2}$, p-doped silicon and an Al rearside contact. A $4 \times 4$ infrared-LED (lightemitting diode)-array that is driven by a fieldprogrammable gate array (FPGA) was used as light source. This results in 16 measurement spots with a diameter of about $3 \mathrm{~mm}$ and a pitch width of $3.5 \mathrm{~mm}$. For the measurements, the photocurrent is recorded every $200 \mathrm{~ms}$. 
Figure $1 \mathrm{~b}$ depicts the principle of the metabolism measurement using the LAPS. During the glucose metabolism processes, the concentration of $\mathrm{H}^{+}$ions within the extracellular space of the cells is increased. The accumulated $\mathrm{H}^{+}$ ions on the LAPS surface contribute to the surface potential, which will influence the space-charge region at the insulator/semiconductor interface. In this way, the LAPS can monitor extracellular $\mathrm{pH}$ changes induced by the metabolism of cells above the LAPS surface.

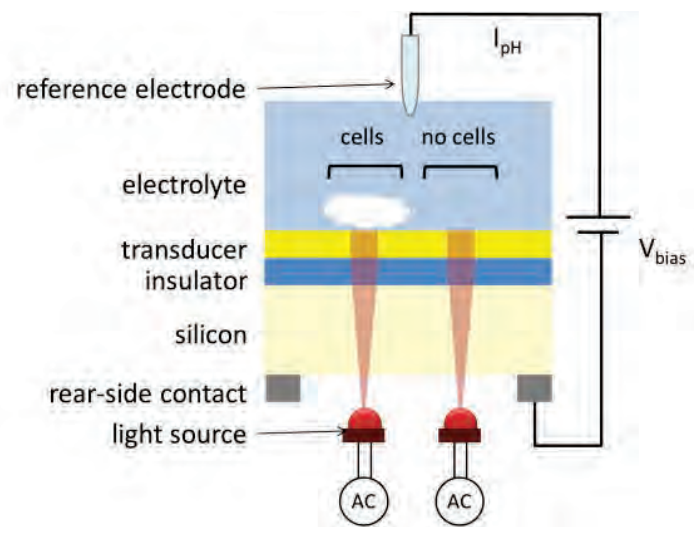

(a)

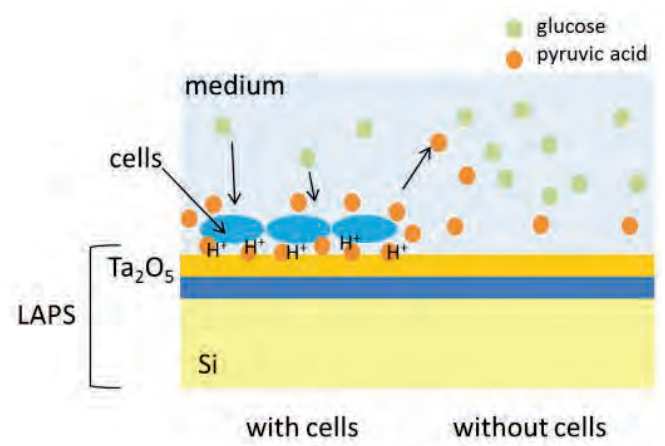

(b)

Fig. 1. Schematic drawing of the LAPS principle.

(a) A bias voltage $V_{\text {bias }}$ is applied across the sensor structure. By utilizing a modulated light pointer, an analyte concentration dependent photocurrent $I_{p h}$ is generated. (b) Cells are immobilized on one half area of the sensor. The concentration of $\mathrm{H}^{+}$ions was modified by the glucose metabolism process of the cells. The accumulated $\mathrm{H}^{+}$ions on the LAPS surface affect the space-charge region on the insulator/semiconductor interface, and hence the recorded local photocurrent.

$\mathrm{CHO}$ cells from the cell line $\mathrm{CHO}-\mathrm{K} 1$ (DSMZ No.: ACC 110) were utilized in the present study as a model system. For the preparation of the culture medium 2/3 dulbecco's modified eagle's Medium (DMEM) and 1/3 HAM F12 were mixed with standard culture medium components such as glucose, glutamine, vita- mins and $5 \%$ fetal calf serum (FCS). The $\mathrm{pH}$ value was adjusted to $\mathrm{pH} 7.0$ and the osmolarity was set to about $330 \mathrm{mosmol} / \mathrm{kg}$. The measurement medium was prepared using the modified RPMI 1640 medium (Roswell Park Memorial Institute, $1 \mathrm{mM}$ phosphate) and 50 $\mu \mathrm{g} / \mathrm{ml}$ of Gentamicin sulphate (Carl-Roth EG: 2157789). The $\mathrm{pH}$ value was adjusted to $\mathrm{pH} 7.0$ and the osmolarity was set to 343 mosmol/kg. Both mediums were stored at $4{ }^{\circ} \mathrm{C}$ in a refrigerator until use.

The acidification rate indicates the average amount of $\mathrm{H}^{+}$ions produced from a single cell per second $[10,11]$; it is calculated as depicted in eq. (1).

$$
\alpha=\frac{\dot{\varphi} N_{A} \beta V}{S n}
$$

Here, $\alpha$ is the average acidification rate $\left(\mathrm{H}^{+} \mathrm{s}^{-1} \mathrm{cell}^{-1}\right), \dot{\varphi}$ is the potential-change rate $(\mathrm{mV} / \mathrm{s}), N_{A}$ is the Avogadro constant, $\beta$ is the specific $\mathrm{pH}$-buffer capacity of the analyte $(\beta=$ $0.79 \mathrm{mM} / \mathrm{pH}$ for measurement medium and $0.15 \mathrm{mM} / \mathrm{pH}$ for PBS), $V$ is the volume of the medium $(300 \mu \mathrm{l}), S$ is the $\mathrm{pH}$ sensitivity of the LAPS structure and $n$ is the number of cells immobilized on the LAPS surface. The potential-change rate $\dot{\varphi}(\dot{\varphi}=\Delta \varphi / \Delta t)$ is calculated by monitoring the surface-potential changes over time.

\section{Results and Discussion}

When a sensor performs a long-term $\mathrm{pH}$ or biological measurement, drift effects of the sensing device cannot be ignored. Also, it is important to evaluate the influence of parameter variations before measuring biological materials. The drift rate of the LAPS chip with cells was about $5 \mathrm{mV} / \mathrm{h}$ and signal variations (rms) for $60 \mathrm{sec}$ were approximately $0.75 \mathrm{mV}$, as shown in Fig. 2. For cell-based biosensors, this drift effect seems to be acceptable, but on the other hand, small $\mathrm{pH}$ changes induced by the cellular activities might not be selectively detected in such cases. To investigate the suitability of the experiment for cell metabolism detection, we performed in addition a control measurement without cells. The medium was exchanged with a new medium several times after the signal was stable. The signal variations by exchanging solutions were determined below $1 \mathrm{mV}$.

To realize the differential measurement set-up, $\mathrm{CHO}$ cells were cultured on the left half-plane of the LAPS chip as shown in Fig. 3a by temporary covering the right half-plane of the LAPS with a metal plate. A sealing underneath the metal plate prevent cell solutions leaching toward the right half-plane. Cells were normally 
cultured over night at $37^{\circ} \mathrm{C}$ in a humidified atmosphere containing $5 \% \quad \mathrm{CO}_{2}$. Figure $3 \mathrm{~b}$ shows the image of the $\mathrm{CHO}$ cells after $4 \mathrm{~h}$ and $18 \mathrm{~h}$ of cell culturing. In this experiment, the proliferation time of $\mathrm{CHO}$ cells on $\mathrm{Ta}_{2} \mathrm{O}_{5}$ was estimated to be $18 \mathrm{~h}$.

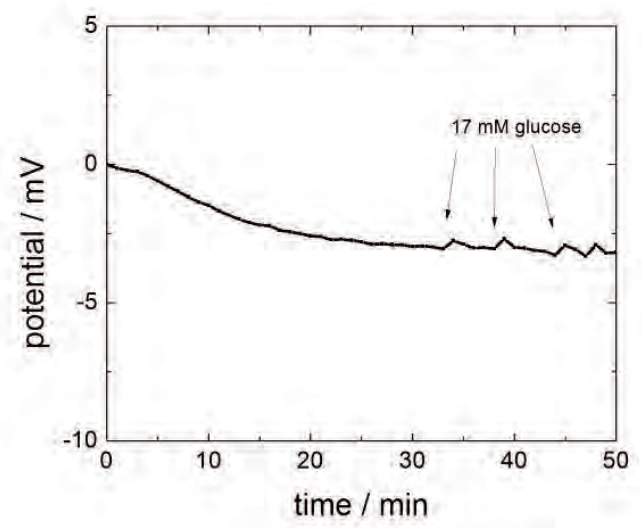

Fig. 2. Response of a LAPS long-term measurement. 30 min later, the medium was exchanged by a new medium.
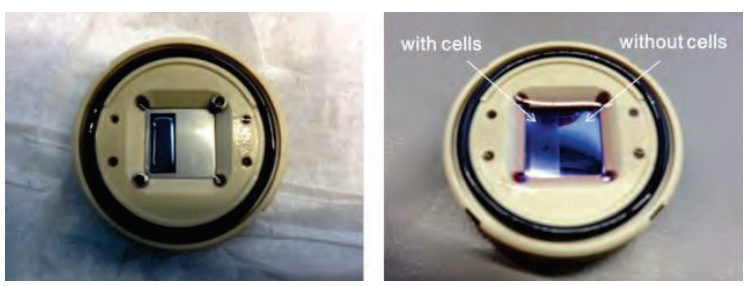

(a)
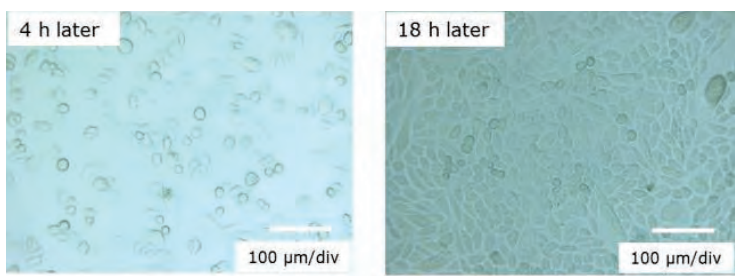

(b)

Fig. 3. Photographs of (a) the culturing of cells on one half of the LAPS chip area and (b) $\mathrm{CHO}$ cells immobilized on $\mathrm{Ta}_{2} \mathrm{O}_{5}$-sensing area of the LAPS.

To evaluate the cell adhesion on the $\mathrm{Ta}_{2} \mathrm{O}_{5}$ substrate, three different cell concentrations were cultured on the LAPS chip for $18 \mathrm{~h}$. The initial cell density, which was put on the LAPS chip at the beginning, should in theory double after $18 \mathrm{~h}$ of cell culturing. The theoretical celldensity value was calculated according to the LAPS-sensing area. The density of cells in the experiment was evaluated by counting the number of cells from a microscopic image. As shown in Table 1, the theoretical and experimental cell densities resulted to be nearly iden- tical. These results indicate a good adhesion of $\mathrm{CHO}$ cells on $\mathrm{Ta}_{2} \mathrm{O}_{5}$ surfaces and that normal cell-culture conditions were achieved in this experimental setup.

Table 1. Comparison of theoretical and experimental cell density after $18 \mathrm{~h}$ of cell culture.

\begin{tabular}{c|cc|c}
\hline $\begin{array}{c}\text { initial } \\
\text { concentration }\end{array}$ & theoretical & experimental \\
\hline $\begin{array}{c}\text { number of } \\
\text { cells / } \\
\text { cells/ml }\end{array}$ & $\begin{array}{c}\text { number of } \\
\text { cells / } \\
\text { cells/ml } / \mathrm{ml}\end{array}$ & $\begin{array}{c}\text { density of } \\
\text { cells / } \\
\text { cells/cm }\end{array}$ & $\begin{array}{c}\mathrm{cm}^{2} \\
\text { density of cells / } \\
\text { cells/cm }\end{array}$ \\
\hline $1 \times 10^{5}$ & $2 \times 10^{5}$ & $0.9 \times 10^{5}$ & $1.0 \times 10^{5}$ \\
\hline $2 \times 10^{5}$ & $4 \times 10^{5}$ & $1.8 \times 10^{5}$ & $1.9 \times 10^{5}$ \\
\hline $3 \times 10^{5}$ & $6 \times 10^{5}$ & $2.7 \times 10^{5}$ & $2.4 \times 10^{5}$ \\
\hline
\end{tabular}

For the following cell metabolism measurements, the cell density on the sensing area was determined to be $4.0 \times 10^{5}$ cells $/ \mathrm{cm}^{2}$. A reference electrode $(\mathrm{Ag} / \mathrm{AgCl})$ was used to apply the bias voltage across the LAPS structure. The measurement medium $(300 \mathrm{ml})$ was changed and the $\mathrm{pH}$ shift resulting from the cell metabolism was observed. To demonstrate a typical measurement example, different concentrations of glucose (17-200 mM) were added to the cell medium and the metabolic reaction was observed. The measurements "with cells" and "without cells" represent the average from eight LAPS-based measurement spots, respectively in Fig. 4a. The absolute value of the surface potential in the area with cells gives a lower value compared to the area without cells. This might be explained by the additional impedance of cells, which affects the capacitance of the sensor during operation. Figure $4 \mathrm{~b}$ depicts the resulting calibration curve due to the cell metabolism. The dependency of the different glucose concentrations follows a typical Michaelis-Menten kinetics like trajectory with $\mathrm{K}_{\mathrm{m}}=32.8 \mathrm{mM}$. These results indicate that cell metabolism measurements were successfully observed by the differential LAPS set-up.

With respect to the differential measurement set-up on a single LAPS chip, the acidification was observed in both areas. However, the acidification rate in the area with cells was higher than that in the area without cells as shown in Table 2. One possible model to explain the small differences in the signal intensities between the two parts of the LAPS chip (with cells and without cells) might be due to 
the fast diffusion of $\mathrm{H}^{+}$ions towards the area without cells. Here, the uncovered $\mathrm{Ta}_{2} \mathrm{O}_{5}$ surface is also able to detect small $\mathrm{pH}$ variations with high precision [12].

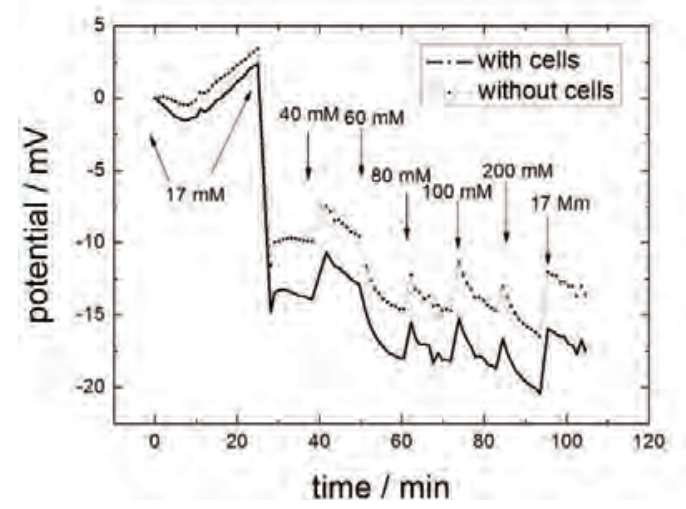

(a)

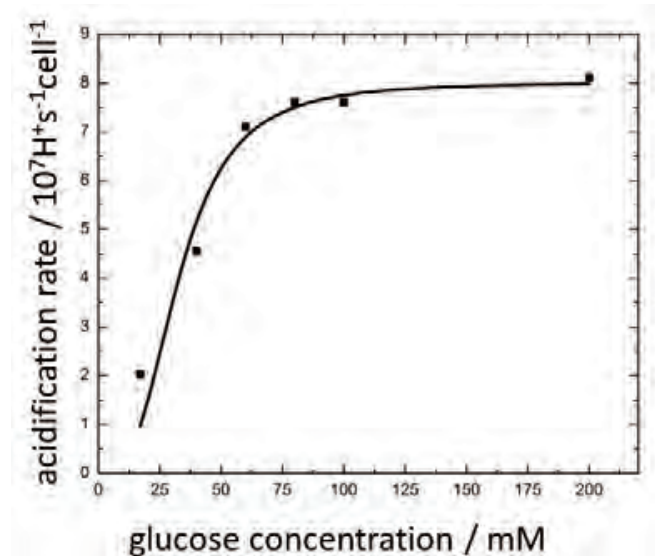

(b)

Fig. 4. Metabolic activity of $\mathrm{CHO}$ cells with respect to varying glucose concentrations (17-200 mM). (a) Response of the $\mathrm{CHO}$ metabolism over time. (b) The metabolism rate was plotted against different glucose concentrations.

Table 2. Comparison of the acidification rate for the area with cells and without cells.

\begin{tabular}{ccc}
\hline $\begin{array}{c}\text { glucose concentration } \\
\text { /mM }\end{array}$ & \multicolumn{2}{c}{ acidification rate $/ \mathrm{H}^{+} \mathrm{s}^{-1} \mathrm{cell}^{-1}$} \\
with cells & without cells \\
\hline 17 & $2.03 \times 10^{7}$ & $1.53 \times 10^{7}$ \\
40 & $4.56 \times 10^{7}$ & $3.11 \times 10^{7}$ \\
60 & $7.10 \times 10^{7}$ & $6.63 \times 10^{7}$ \\
80 & $7.61 \times 10^{7}$ & $6.12 \times 10^{7}$ \\
100 & $7.61 \times 10^{7}$ & $7.60 \times 10^{7}$ \\
200 & $8.11 \times 10^{7}$ & $7.14 \times 10^{7}$ \\
\hline
\end{tabular}

\section{Conclusions}

To evaluate the cell adhesion on $\mathrm{Ta}_{2} \mathrm{O}_{5}$ substrate, the consistency between theoretical and experimental values in cell culturing was confirmed. The good adhesion of $\mathrm{CHO}$ cells on the $\mathrm{Ta}_{2} \mathrm{O}_{5}$ surface was observed and cells can be cultured under normal conditions within this experimental set-up. This is important to guarantee a regular response of the cells under investigation. The metabolic activity of $\mathrm{CHO}$ cells for different glucose concentrations (17$200 \mathrm{mM}$ ) has been studied. The $\mathrm{pH}$ changes increased with an increase in glucose concentration. The dependency of the different glucose concentrations depicts a MichaelisMenten kinetics like trajectory with $\mathrm{K}_{\mathrm{m}} 32.8 \mathrm{mM}$. Comparing the signal in the area with cells and without cells, the acidification was observed in both areas. However, the rate in the area with cells is slightly higher than that in the area without cells. In conclusion, the results suggest that an isolation of the solutions between both measurement areas is beneficial for differential measurements on a single sensor chip. In this experiment, we demonstrated the prospect to observe the cells metabolism using a LAPS device. In further experiments, a microfluidic system for the differential measurement on LAPS should be developed to overcome variations of measurements parameters and to hinder undesired $\mathrm{H}^{+}$-ion diffusion. The ongoing development of an integrated micro-fluidic system based on LAPS, might be helpful to monitor cell activities more precise and reliable in the future.

\section{References}

[1]R.L. Stears, T. Martinsky and M. Schena, Trends in microarray analysis, Nature Medicine 9, 140-145 (2003); doi: 10.1038/nm0103-140

[2]T. Elad, J.H. Lee, S. Belkin and M.B. Gu, Microbial whole-cell arrays, Microbial Biotechnology 1, 137-148 (2008); doi: 10.1111/j.17517915.2007.00021.x

[3]L. Prix, P. Uciechowski, B. Böckmann, M. Giesing and A.J. Schuetz, Diagnostic biochip array for fast and sensitive detection of K-ras mutations in stool, Clinical Chemistry 48, 428-435 (2002); pmid: 11861435

[4]D.G. Hafeman, J.W. Parce and H.M. McConnell, Light-addressable potentiometric sensor for biochemical systems, Science 240, 1182-1185 (1988); doi: 10.1126/science. 3375810

[5]J.C. Owicki, L.J. Bousse, D.G. Hafeman, G.L. Kirk, J.D. Olson, H.G. Wada and J.W. Parce, The light-addressable potentiometric sensor: principles and biological applications, Annual Review of Biophysics and Biomolecular Structure 23, 87-113 (1994); doi: 10.1146/annurev.bb.23.060194.000511 [6]M.J. Schöning, T. Wagner, C. Wang, R. Otto and T. Yoshinobu, Development of a handheld 16 channel pen-type LAPS for electrochemical sensing, 
Sensors and Actuators B: Chemical 108, 808-814 (2005); doi: DOI:10.1016/j.snb.2005.01.055

[7]T. Wagner, T. Yoshinobu, C. Rao, R. Otto and M.J. Schöning, "All-in-one"solid-state device based on a light-addressable potentiometric sensor platform, Sensors and Actuators B: Chemical 117, 472479 (2006); doi:10.1016/j.snb.2005.12.056

[8]Y.G. Mourzina, M.J. Schöning, J. Schubert, W. Zander, A.V. Legin, Y.G. Vlasov and H. Lüth, Copper, cadmium and thallium thin film sensors based on chalcogenide glasses, Analytica Chimica Acta 433, 103-110 (2001);

doi: 10.1016/S00032670(00)01384-2

[9]T. Wagner, R. Molina, T. Yoshinobu, J.P. Kloock, M. Biselli, M. Canzoneri, T. Schnitzler and M.J. Schöning, Handheld multi-channel LAPS device as a transducer platform for possible biological and chemical multi-sensor applications, Electrochimica Acta 53, 305-311 (2007);

doi: 10.1016/j.electacta.2007.04.006
[10]J. Owicki and P. Wallace, Biosensors based on the energy metabolism of living cells: the physical chemistry and cell biology of extracellular acidification, Biosensors and Bioelectronics 7, 255-272 (1992); doi: 10.1016/0956-5663(92)87004-9

[11]C.F. Werner, C. Krumbe, K. Schumacher, S. Groebel, H. Spelthahn, M. Stellberg, T. Wagner, T. Yoshinobu, T. Selmer, M. Keusgen, M.E.M. Baumann and M.J. Schöning, Determination of the extracellular acidification of Escherichia coli by a light-addressable potentiometric sensor, Physica Status Solidi A 208, 1340-1344 (2011); doi: 10.1002/pssa.201001141

[12]M.J. Schöning, D. Brinkmann, D. Rolka, C. Demuth and A. Poghossian, CIP (cleaning-in-place) suitable "non-glass" pH sensor based on a $\mathrm{Ta}_{2} \mathrm{O}_{5}-$ gate EIS structure, Sensors and Actuators B: Chemical 111, 423-429 (2005);

doi:10.1016/j.snb.2005.03.053 